Grand Valley State University

ScholarWorks@GVSU

$12-2011$

\title{
Teaching in Educational Leadership Using Web 2.0 Applications: Perspectives on What Works
}

\author{
E. J. Shinsky \\ Grand Valley State University, shinskjo@gvsu.edu \\ Hans A. Stevens \\ Alpena Public Schools
}

Follow this and additional works at: https://scholarworks.gvsu.edu/coe_articles

Part of the Education Commons

\section{ScholarWorks Citation}

Shinsky, E. J. and Stevens, Hans A., "Teaching in Educational Leadership Using Web 2.0 Applications: Perspectives on What Works" (2011). Peer Reviewed Articles. 8.

https://scholarworks.gvsu.edu/coe_articles/8

This Article is brought to you for free and open access by the Education at ScholarWorks@GVSU. It has been accepted for inclusion in Peer Reviewed Articles by an authorized administrator of ScholarWorks@GVSU. For more information, please contact scholarworks@gvsu.edu. 
Journal of Research on Leadership Education

December 2011, Volume 6, Issue 5

\title{
Teaching in Educational Leadership Using Web 2.0 Applications: Perspectives on What Works
}

\author{
E. John Shinsky \\ Grand Valley State University \\ Hans A. Stevens \\ Alpena Public Schools
}

\begin{abstract}
To prepare 21st Century school leaders, educational leadership professors need to learn and teach the utilization of increasingly sophisticated technologies in their courses. The co-authors, a professor and an educational specialist degree candidate, describe how the use of advanced technologies - such as Wikis, Google Docs, Wimba Classroom, and Discussion Board - have served as a catalyst for learning among educational leadership students. Details regarding how technology has been used in one course are described, demonstrating how various apps and software applications can easily be applied in other courses.
\end{abstract}

The landscape of education in both K-12 and higher education is changing with the ongoing expansion of technology (Culp, Honey, \& Mandinach, 2005; Kent \& McNergney, 1999). School and district administrators are faced with a significant challenge as they lead efforts to implement various facets of technology throughout school and district settings - exploring ways to improve student achievement; enhance student and staff skills; access information; create a strong infrastructure; engage the community, and prepare students to be productive citizens, employees, and leaders in the $21^{\text {st }}$ Century. School leaders must focus on equipping students and staff with the necessary skills to survive and flourish in a global society that is undergoing significant transformation. At the same time, college and university professors must prepare highquality leaders who can successfully lead educational systems that are in the midst of radical change (Kinglsey, 2010). As educational leadership professors contemplate the best ways to prepare school leaders to address current and future challenges, the use of technology clearly is a viable resource for expanding knowledge, engaging learners, and enhancing skills that can be used for $21^{\text {st }}$ Century leadership preparation.

This article discusses various ways educational leadership professors can use advanced technology tools to enhance the learning process for current and aspiring school and district leaders (Grey-Bowen, 2010; Jackson, 2009). A focus is on authentic, project-based activities which utilize technologies that promote active engagement, participation in groups, frequent interaction and feedback, and connection to real-world 
experts (Edutopia Staff, 2008; Reynolds \& Caperton, 2009; Woo, Herrington, Agostinho, \& Reeves 2007). Featured technology tools include Wikis, Discussion Board, Google Apps, and Wimba Classroom - all of which facilitate collaborative planning and learning, and the use of technology in a routine, transparent manner to support course goals. In addition, the professor who teaches a course using authentic, project-based technology-embedded activities, and a student, share their perspectives regarding how effective these tools were in engaging students in a specific collaborative project design that promoted creativity, innovation, critical thinking, problem solving, communication, and learning for adult learners (Carroll, 2011; Herder \& Marenzi, 2010; Conole \& Alevizou, 2010).

\section{Description of the Course}

The course highlighted in this article is Organizational and Community Relations, which is part of the Educational Specialist graduate program at the primary author's university. This course provides a thorough examination of the school district as an organization and its interactions with the community. Consideration is given to internal and external communities and the relationships between and among these entities within a school district. A major focus of this course is the implementation of communication and engagement strategies that focus on establishing effective partnerships, creating an informed community, and working effectively with the media, social networking, and using technology to maximize the scope, efficiency, and accuracy of communication throughout all aspects of the community. This course supports the Standards for Advanced Programs in Educational Leadership as developed by the Educational Leadership Constituent Council (ELCC) (2002), a member of the National Council for Accreditation of Teacher Education. In addition, students are required to meet the Michigan Department of Education Technology Standards (MDETS) (2009).

\section{The Implementation of Technology in Educational Leadership Courses}

As university professors, we have an exceptional opportunity to transition from face-to-face teaching to high-quality, online-accessible, 24/7 education for educational leaders. This is important because technology is an evolving industry that requires ongoing training and application for maximum proficiency (Christensen, 2002). It is particularly important for university professors in educational leadership, because most of us grew up and were educated when technology was in its infancy. It is now an integral part of our daily lives and is essential to the growth of educational systems and our society as a whole (Abrego \& Pankake, 2010).

In addition to enhancing our own skills, we have to emphasize the importance of ongoing technology training for our students. Typically, our program candidates are adults with families, employed in responsible jobs, with limited time to invest into learning technology (Barnett, 2010; Ginsburg, Sabatini, \& Wagner, 2010; Sander, 2010). However, students who are taking our courses have committed their time to learning and have made it a priority to expand their knowledge. Thus, it is incumbent upon us as professors to provide our students with the best educational opportunities possible 
while equipping them with the knowledge and skills needed to provide leadership in effectively expanding the use of technology.

This process begins with the leadership of university professors who naturally embed technology into their courses and become models for the use and application of technology. The Internet has given educators access to up-to-the-minute information and research, access to educational leaders from around the world, and the opportunity to integrate text, audio, video, and pictures with collaboration tools that enhance our ability to effectively teach and facilitate meaningful learning.

While working with this exceptional opportunity, we must be mindfully responsible about the manner in which we use the technology and build the foundation for its acceptance and future growth. The research of Byun, Hallett, and Essex (2000) and Liu (2001) reinforces the importance of building a quality foundation for infusing technology; pedagogy is of primary importance and using strategic methods to orchestrate learning is essential. To reach this end, the following approaches can be used to promote learning and the meaningful use of technology in university courses:

- Identify strategies for effective online instruction.

- Define guiding principles for quality online course design.

- Transition students from passive learning to engagement.

\section{Identify Strategies for Effective Online Instruction}

To be effective, professors engaged in online instruction need best-practice strategies to facilitate meaningful learning and take into account the broad diversity of student knowledge and experience regarding content and use of technology (Groth, Dunlap, \& Kidd, 2007; Kidd, 2010; Rice, 2009; Thomas \& Knezek, 2008). The following review of literature helps create an understanding of what Reushle (2006) referred to as an environment that sustains motivation in a climate that is positive, supportive, safe, tolerant, respectful, nurturing, and participatory. In order to promote such as environment, an effective instructor of an online course may pursue the following actions.

According to Pasco and Adcock (2007), effective online instructors facilitate learning as opposed to being the center of learning. They understand online learning, the structure of the learning environment, and relationship building with learners promotes learner self-regulation, summarizes student learning by asking thoughtful questions, builds connections with prior learning and future practice, elicits reflective thinking, and promotes problem-solving (Norton \& Hathaway, 2008). Effective online instructors create high-quality course materials and assignments that are professionally meaningful, and the professors assure there is high-quality feedback and communication (Tricker, Rangecroft, Long, \& Gilroy, 2001). Sprangle, Hodne, and Schierling (2007) emphasized the value of good written skills, the ability to carefully design activities that promote discussion, and timely feedback. Instruction is adapted to student needs with meaningful examples shared, student motivation to do their best, 
while facilitating the course effectively, delivering a valuable course, communicating effectively, and showing concern for student learning (Young, 2006).

\section{Define Guiding Principles for Quality Online Course Design}

Online instruction is continuing to evolve at universities across the United States. Therefore, faculty members within Educational Leadership programs have a significant opportunity to influence their students' perspectives regarding current and future use of technology. In attempting to define the guiding principles of a quality program to incorporate into online coursework, some faculty members have focused on what will achieve transformative learning outcomes in both student perspectives (i.e., how they view the world and their work) and action (i.e., how this translates to their practice). Instructors who strive to incorporate quality principles into their online teaching can do so by referring to the following key points highlighted in the research of Reushle (2006):

- Establish the connectivity, humanness, and empathy (CHE) factor;

- Promote a learner-centered online environment;

- Help students immerse and reflect;

- Make learning a community activity;

- Show how educators and learners both lead and learn;

- Maintain visible, instant, and permanent (VIP) communication;

- Interpret and respond to signs of change;

- Lead by example and create a model experience;

- Build, manage, and revise the online learning environment;

- Motivate and prepare students, and

- Transition students from passive learning to engagement.

In the following section, a brief description is provided that reflects how each of the principles was implemented in the Organizational and Community Relations course.

Establish the connectivity, humanness, and empathy (CHE) factor. An in-depth conversation occurs about the purpose of using online learning; its technical components, exploratory aspects, and value; potential technical issues that could arise, and how to be a supportive community of learners. A community-building activity takes place at the beginning of the course, where students introduce themselves to each other and share their current positions, educational history, and interest in the course. This virtual small-group activity provides students with an opportunity to meet and carry out some initial interactions online, so technologically experienced and inexperienced learners can become more familiar and comfortable with the technology.

Promote a learner-centered online environment. Ongoing discussions take place about the value of learning from each other, the unique expertise each student brings to the course, and how they can collaborate effectively on project development and problem solving. 
Help students immerse and reflect. Students are provided with authentic, challenging situations as part of their journal and discussion board activities. This requires dialogue and both individual and group problem-solving strategies.

Make learning a community activity. Students are required to complete a final project as part of a collaborative team. Every member of the team has a role, and all are required to work together using technology to successfully complete the project.

Show how educators and learners both lead and learn. Final project teams are encouraged to identify an overall team leader. However, leadership for various project responsibilities is delegated to individual team members who have the skills or interest.

Maintain visible, instant, and permanent (VIP) communication. For many students, this course is the first experience they have had with online learning and teaching. Therefore, all deliberations and work completed online, including formal and informal discussions, are maintained in permanent, available-on-demand formats. This creates significant learning opportunities, leaving a major impression on the students. In this online course, the instructor maintained VIP communication by responding to all communications within a 24 hour period, facilitating ongoing online discussions with instructor involvement, posing questions to promote deeper understanding of discussion board and journal assignments, and sending routine emails to all candidates highlighting the key components of assignments, research, and authentic project work.

Interpret and respond to signs of change. Discussions take place about the pedagogical changes that are occurring based on the use of technology and the change of venue from face-to-face to online. Students are asked to provide ongoing feedback about their perceptions of change and ways that it could be enhanced to make it an even more meaningful process.

Lead by example and create a model experience. The online course is planned with attention to detail to avoid problems that might reflect poorly upon the use of the technology. For example, all URLs are thoroughly reviewed to ensure they function properly and provide the most current links to web pages and support materials. Also, we model the use of technology and demonstrate its potential benefits for the course and the students' work environments. Students are reminded that technology has its flaws and that the inevitable mishaps are an opportunity for everyone to learn.

Build, manage, and revise the online learning environment. Discussions occur with students about how online learning technologies are at the beginning stages of implementation and that there will be challenges that need to be worked out. Student feedback is highly encouraged, and students are provided with an ongoing opportunity after every class to complete a Keep/Add/Drop Feedback Form. This helps the instructor understand what the students view as meaningful and gathers their suggestions about what can be done to enhance their learning. All student suggestions are used as a resource for revising and improving the online course.

Motivate and prepare students. Establishing a climate of support, respect, risktaking, collaboration, and ongoing nurturing is integral to establishing trust and building the students' enthusiasm to embrace technology - both in the course itself and in their work environments. Beginning the course with an open and honest 
discussion about the intricacies of the technology used in the course, recognizing the various levels of candidate experiences in using technology, and establishing norms for working together both as a class and as members of project teams were three approaches used to establish a climate of sensitivity, respect, and support. Candidates were routinely asked about their comfort levels regarding the use of technology and offered various options for addressing issues and expanding the use of the technology through peer or instructor support, or technical support from instructional technology.

\section{Transition Students from Passive Learning to Engagement}

After teaching this course for the past three years, it continues to be evident that there is a wide variation in the students' knowledge, skills, and experiences in both the subject area and the use of technology. Teaching an online course under these circumstances requires skillful, thoughtful, and reflective practice in teaching that engages students and moves them along the spectrum of learning.

One useful resource for planning effective online lessons is Bloom's Digital Taxonomy, as described by Andrew Churches (2009). It serves as a practical resource for scaffolding learning and offers a framework for engaging students regardless of their level of competence in using technology. This is a critical planning resource as students participating in the online course move along the taxonomy through a combination of learning activities in their journals, discussion board, and final projects. Brief examples of how Bloom's Digital Taxonomy is used in Organizational and Community Relations are explained in the following list.

Remembering. Students are required to identify specific websites as resources and bookmark them for current and future use. (Focus: Bookmarking)

Understanding. Students have to respond to situations in their journals and communicate with peers about how they formed a perspective on a particular issue. (Focus: Journaling)

Applying. Final project teams become cooperative learning groups that orient and equip their members with the skills needed to use tools like Wikis so they become proficient, contributing members of the team. (Focus: Uploading and Sharing)

Analyzing. As part of the students' final projects, they are asked to gather and analyze data and determine the scope of the problem they are going to address. The data they gather serve as a baseline for demonstrating results that will come about as a result of implementing their project. (Focus: Validating)

Evaluating. Students participate in journal and discussion board communications where they critique, respond, judge, and contribute their perspectives about an issue being discussed. (Focus: Critiquing, Judging, and Reflecting)

Creating. Team members create a final product, which represents a collaborative effort using Google Apps, a Wiki, and other similar tools. (Focus: Directing and Producing)

What we teach in educational leadership programs has a profound, direct effect on what happens in our K-12 schools today and in the future. As Anderson and Dexter's (2005) research has confirmed, although technology infrastructure is important, a principal's technology leadership skills are even more critical to instilling 
the use of technology as a learning and productivity tool in schools. Our work as professors, and how we model the use of technology, becomes even more important as we move beyond the past to a new future. We need to avoid what Zemsky and Massy (2004) described: "... that even when faculty use e-learning for instruction, they still teach as they were taught - providing lectures to supply basic knowledge to students" (p. iii).

\section{Sample Lesson Using Technology: The Final Project}

This sample lesson focuses primarily on the final project for the Organizational and Community Relations course. In addition, other journal, discussion board, and technology assignments are discussed, providing insight into strategies that can be used to expand students' skills with technology.

The final project is a project-based learning experience that is authentic, studentand community-focused, and embeds the skills leaders need to manage complex communities in the midst of dramatic change. The focus of the final project is to create a comprehensive plan that (a) is applicable to the field and (b) demonstrates the potential for having a direct influence on improving student performance in the K-12 setting.

The final project is strategically designed to incorporate key course content into the culminating experience while placing major emphasis on demonstrating competence in the various leadership standards described in the Standards for Advanced Programs in Educational Leadership, as developed by the ELCC, and the Michigan Department of Education Technology Standards (MDETS). An example of the specific components of the culminating experience can be found in the Final Project Description. In addition, a description of the final project provided to the students follows:

This project requires you to work as a member of a team to create a quality School Community Relations Plan that incorporates research, practice, and various resources into the final document. The Final Project is designed to assess your ability to use and apply multiple resources and skills, generated from various sources and experiences throughout the course. Your team should begin working on the Final Project during and/or after the first session of class. All teams are required to use a Wiki or Google Apps as collaboration technology in the development and submission of the project. Specific details relating to the Final Project can be accessed in the Assignment area in Blackboard.

\section{Developing the Final Project}

To begin, small groups are formed for the final projects by identifying individuals who have common interests. Then, prior to project development, students are given various opportunities to finalize their teams and prepare for their independent work together.

The final project has three distinct components for student learning: 
1. Designing an authentic, practical project that has a direct, positive influence on the organization and community

2. Developing $21^{\text {st }}$ Century skills, which include critical thinking, information and media literacy, creativity, communication skills, collaboration, and contextual learning (Partnership for 21 ${ }^{\text {st }}$ Century Skills, 2002)

3. Expanding personal knowledge about the use and application of technology

As noted previously, students are required to use technology to complete their projects and may choose between Google Apps and a Wiki in Blackboard as the collaboration tool of preference. An orientation to the collaboration tools is provided by either the instructor or a student knowledgeable in the use and application of the technology. Step-by-step procedures have been set up for using Google Apps (How to Develop and Use Google Apps for Collaborative Projects) and the Blackboard Wiki (How to Develop and Use a Wiki for Collaborative Projects) which serve as a resource for students and also professors interested in using these tools in their courses. Each of these tutorial documents was created with Jing. An easy, step-by-step process for using Jing to create tutorials can be accessed by going to www.techsmith.com/jing or A Stepby-Step Process for Using Jing for Screen Captures.

As students continue to work through the course, additional technology skills are introduced through various activities in four different areas, with specific details provided for professors interested in incorporating these into their course: (a) skill development readings, (b) discussion board assignments, (c) journal assignments, and (d) general assignments. These activities are designed to familiarize students with various resources on the Internet, provide further skill development, and expand upon learning to address various standards. Each of these experiences is also designed to build a foundation of common skills so students can function more cohesively as members of their final project teams.

\section{Completing the Final Project}

At the end of the course, students share their presentations with the entire class. The quality of the final projects are determined by using a rubric: Level of Performance Rubric for the Final Project. Students are asked to provide feedback regarding how well they felt their projects met the specific MDETS standards. This is another strategy used to facilitate learning, personal reflection, and critical thinking, and to actualize the components of Bloom's Digital Taxonomy (Churches, 2009). An example of student feedback regarding Math Mentors - the project featured in the next section - can be found at Student Reflection on Michigan Technology Standards and Final Project.

\section{Building an Online Learning Community}

The students participating in the online course are a combination of current administrators and aspiring leaders who have a range of abilities in working with their internal and external communities. Since this is a community relations course where building relationships is critical, the work begins by establishing a community of learners within the online course. 


\section{Shinsky \& Stevens/TEACHING USING WEB 2.0 APPLICATIONS}

There are a number of ways to create a learning community in a course. However, when teaching online, this becomes even more important because face-to-face contact among the students is limited or nonexistent. Therefore, a top priority is to establish quality relationships as early as possible so the students can focus on the critical aspects of learning. Five processes for creating a cohesive community of online learners, developed by a faculty professional development team at the primary author's university include: (a) focus on the person, (b) establish norms, (c) begin relationship building, (d) develop rigor, and (e) continue to build the total community.

Focus on the person. Foster a sense of belonging and value by letting students know how important their input and contributions are to the learning community. Communicate routinely about the design of the online course and how it is an ongoing process that will improve with their participation and feedback. Finally, engage students in meaningful and thoughtful conversations about course content through ongoing email communications, setting up formal and informal discussion forums, meeting with students face-to-face, and making personal phone contacts to discuss student status and needs. This is especially important because online courses can promote isolation unless the instructor encourages participation (Liu, Magjuka, Bonk, \& Lee, 2007; Northcote, 2008; Palloff \& Pratt, 2011).

Establish norms. Online courses are a new experience for many students. While the norms for an online course are similar to those of a face-to-face course, the instructor must be sensitive to the dynamics of what is taking place (Hill, 2002). The way students interact online, without being able to visually read facial and body language, can significantly affect their satisfaction, retention, and learning. Some key norms include support and respect - where members are encouraged to participate and contribute individually and collectively, everyone's opinions are valued, and all students have a responsibility for learning.

Begin relationship building. All classes should begin with a relationshipbuilding activity. This activity should be designed to share something personal, seeking the common interests that build connections among students. Initially, students can be asked to post information on the discussion board describing what they do, their interests, their hobbies, what they like to read, trips they have taken, and their aspirations.

Develop rigor. Students should be provided with some thought-provoking questions that challenge their thinking and help them begin to stretch their learning. Video clips can be used to stimulate conversation on the discussion board, followed by thought-provoking questions.

For example, in one discussion board activity for the course, students are asked to watch an ABC News video clip about how our urban schools are failing. Then small groups of students are asked to discuss various questions such as, "How can we defend our educational programs to our community when we have these poor results?" "What needs to be done to rally our community together to reverse this trend?" "If we do not work in an urban system, why should we be concerned about this issue?" An example of this activity is provided in the Wimba Classroom Discussion Board Activity. In 
addition, a step-by-step process for Using Discussion Board for Collaborative Projects is provided for professors interested in developing thought-provoking and engaging activities.

Continue to build the total community. To continue to build the learning community, engage students in several different group activities during each class, with members changing routinely. For example, one of the exceptional technology resources used to establish a cohesive learning community in this course is Wimba Classroom. Wimba Classroom includes a number of components that engage students with a variety of technology tools, which seamlessly combine interactive technologies with instruction. Some of the key tools used in this course include audio, video, pictures, whiteboard, breakout rooms, emoticons for communicating, polls, project sharing, and archiving. The strategic use of these tools allows students to interact, collaborate, create, and communicate in ways that are very similar to face-to-face instruction and significantly enrich the delivery of content to make it interesting, interactive, and meaningful.

Within these tools, various video vignettes are highlighted, showing a superintendent interacting with his community regarding the district budget deficit and the community relations plan, engaging the educational community, and dealing with difficult decisions. Students are asked to select a vignette and analyze various aspects of the presentation in relation to effective leadership and communication during difficult times.

Examples of course content designed to engage students and provide them with authentic information through video and URL access in Wimba Classroom are shown in Wimba Classroom Video Activity.

\section{Completing the Final Project}

\section{A Final Project: A Student's Perspective}

Our final project for Organizational and Community Relations was to develop a community relations plan that incorporated research, practice, and a variety of resources. Three of our four team members were involved in Title I leadership during our participation in this class, so it made sense to do something involving the parent involvement component of Title I. After some preliminary discussion, we settled on mathematics as a priority; even at the elementary level, it has been our experience that parents struggle to know how to help their children in this critical core area. Our goal was to design a plan to bring together resources to help parents become partners in their children's mathematical development. We titled our endeavor Math Mentors.

Early on, we decided to depart from the traditional slideshow for presenting our project in favor of creating a website. This was for two reasons. First, two of our team members had completed a website for a previous class in the university's Educational Specialist degree program, and both the process and the final product had been wellreceived. Second, since we intended to put this plan into practice, we felt that a website would become an ongoing tool for collaborating with leaders, communicating with partners, collecting resources, and disseminating information to participants in the Math Mentors initiative. It seemed sensible to invest our efforts in a useful final 
product, and we felt it was a good way to further explore our district's new set of online productivity tools, Google Apps for Education.

\section{Google Apps for Education}

Google Apps for Education is a suite of cloud-based applications that Google provides free to educational institutions. Unlike traditional computer programs which must be installed on the user's computer, cloud-based applications are available to users from any Internet-connected computer using a browser. Because the software and data exist on the web, cloud-based programs can run seamlessly from a wide variety of computers and mobile devices.

The Google Apps for Education cloud-based suite includes e-mail, a calendar, website creation software, and a set of office applications for word processing, spreadsheets, drawings, slideshows, and surveys. The online workspace also can function as a file locker, where a variety of documents can be uploaded for storage and sharing. Since these applications and the associated work files reside in the cloud, we had access to our work from any Internet-connected computer, providing maximum flexibility to our team. Also, several of the tools include real-time collaboration capabilities, with integrated chat and the ability for multiple team members to work on a product simultaneously. This appealed to us as busy professionals.

We had access to the Google Apps for Education suite of online tools through our school district, which at the time had been using the suite for approximately 10 months. I had helped spearhead the implementation of Google Apps for our district. Two other members of the final project team were employees of my district. One had done a fair amount of exploring the suite's capabilities, while the other had not advanced much beyond use of the suite's e-mail application, known as Gmail. The fourth member of our team was employed by a different district, but since he had access to a Gmail account, it was not difficult to make him a full collaborator with complete access to the project.

Our Math Mentors project relied heavily on the website creation application in the suite, called Sites. We also used the office applications, called Google Docs, for word processing to collect our ideas. The Google Docs home became a file locker for uploading Word, Excel, and PDF files such as the project budget. The final project can be viewed at https://sites.google.com/a/alpenaschools.com/math-mentors/home. The chart provided in Google Tools Used for the Math Mentors Project, summarizes the tools used for this project, the reason we chose them, and the steps involved in using each tool to accomplish the task.

\section{Final Project: The Process}

In the early stages of our project, one of our team members e-mailed a word processed document of initial thoughts about the project based on the course syllabus. The first tool we used was the Google Docs word processor. This program offers users easy access to a live version of the file, permitting multiple users to edit one common, shared document simultaneously. In addition, a comprehensive revision history is kept for every change, so there is a complete audit trail of who made what changes. 
Documents can be created and shared within Google Docs, but the program can also convert standard word processing documents into online versions.

Uploading a document from an e-mail attachment is a simple, two-step process within the Google Apps Gmail application. Word processed documents attached to a message in Gmail come with a link to "View" the attachment. Clicking on this opens the document in the Google Apps viewer. From this point, clicking the "Edit" button adds the document to the user's Google Docs document list. Once it is converted to a Google Doc for editing, sharing the document is just as easy. Clicking on the "Share" button brings up a dialog box where a user can set the level of sharing. By entering the e-mail addresses of desired viewers or collaborators, one may grant either read-only or collaborative editing access to the file. Figure 1 shows a sample of the sharing dialog box.

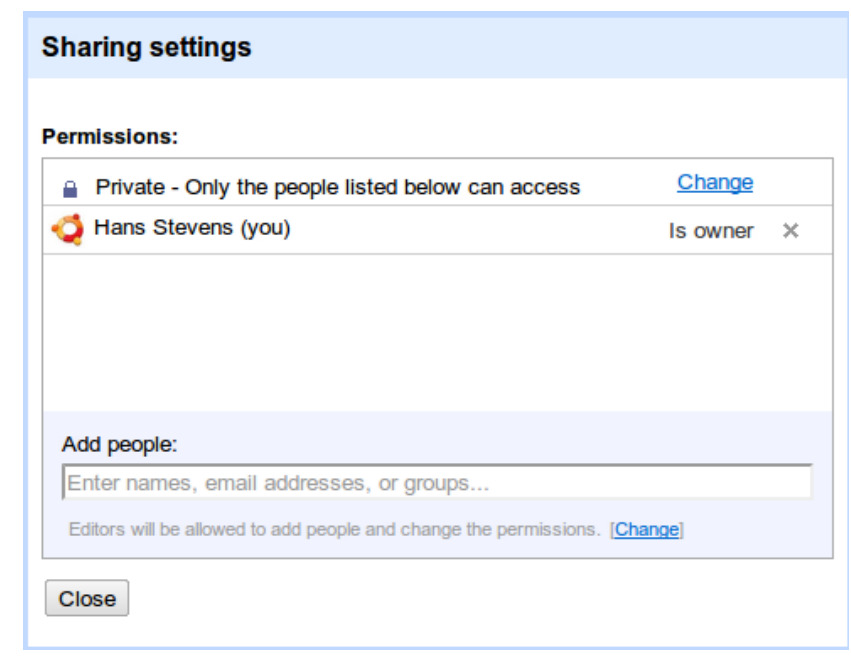

Figure 1. Sample of the sharing dialog box in Google Docs.

We used this first document as an initial place to generate and share ideas. Much of the structure and text of the final site came from the brainstorming and sharing within this document.

Fortunately, working with a Google Docs document looks very familiar to any computer user. Figure 2 shows a view of the Google Docs word processing toolbar.

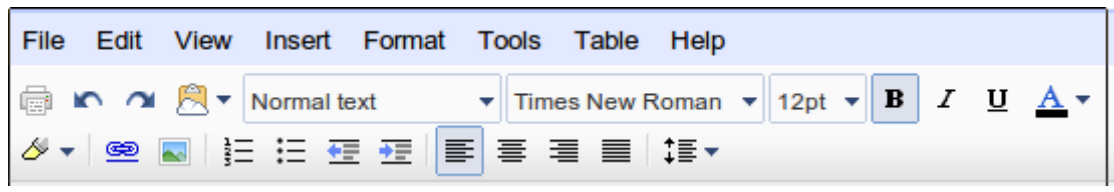

Figure 2. Google Docs word processing toolbar. 
The standard editing tools and familiar menu structure are what computer users have come to expect from word processing software. The difference is that this software is cloud-based. Since it is available through an Internet browser, it is accessible wherever the user is and from any computer, enhancing convenience and flexibility.

Once created or converted into online documents, Google Docs items can be downloaded in a variety of forms, including Adobe PDF. Since PDF is a universal format with a freely available viewer, many online documents are posted in this format. One of the documents we posted to our website in PDF format was a draft "Math Mentors Topic and Activity List." This document, found on the site's "Resources" page, was originally a word processing document that we uploaded to Google Docs. We then used Google Docs to generate a PDF for posting by choosing "Download" from the open document's "File" menu and picking "Adobe PDF" as the desired download format. The purpose of generating a PDF for posting is that it is more accessible for students who used various platforms and the memory size is much lower.

As mentioned previously, Google Docs can also store a variety of file formats in their original format, acting as an online file locker. Once in storage, these items can be added as links in a website. We used this capability with the topic and activity list and with our project budget, which one of our team members provided already converted into a PDF. Within the Google Docs document list, there is an "Upload" button. Clicking this brings up a dialog box (Figure 3), which gives the user instructions for either browsing for the file to upload or dragging and dropping files from the user's desktop. Also, the box includes checkboxes to set conversion options; files can be uploaded as they are in a read-only format, or compatible files can be converted to an editable Google Docs format. Once these options are set, clicking the "Start Upload" button adds the files to the document list.

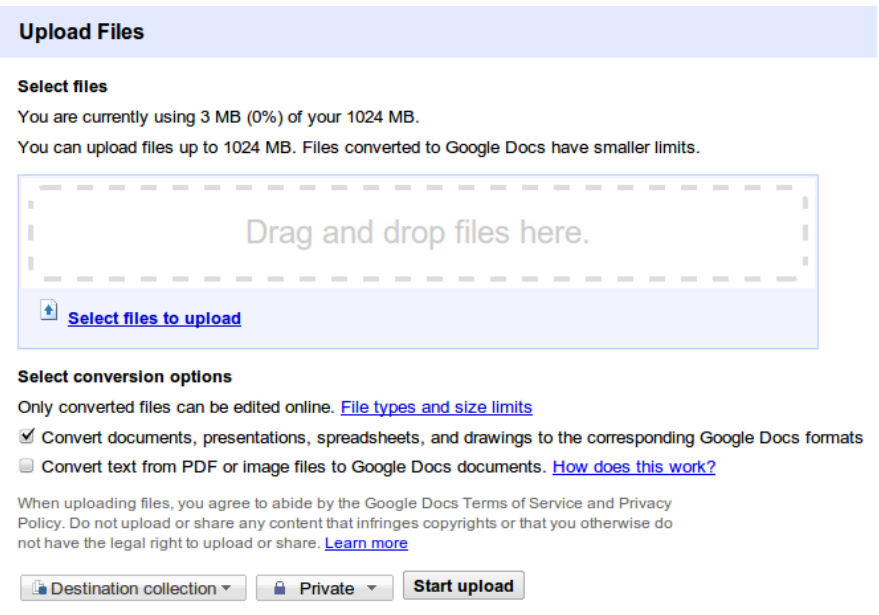

Figure 3. Upload button in Google Docs.

The Math Mentors site itself was created using Google Sites. This online application is accessible through the user's Gmail account. Google Sites allows users to 
set up a professional-looking website without having any special software or html programming skill.

Establishing a new website begins by clicking "Create New Site" in Google Sites. On the screen that appears (Figure 4), users can select from a number of established templates or choose the default blank template, which is the option we selected. Here is where the name of the site is established, and the color theme and other options can be chosen. It is important to note that most of the options can be changed once the site is created. Finally, clicking "Create Site" at the bottom of the screen finishes the initial site creation process and opens a blank home page where the user begins adding content.

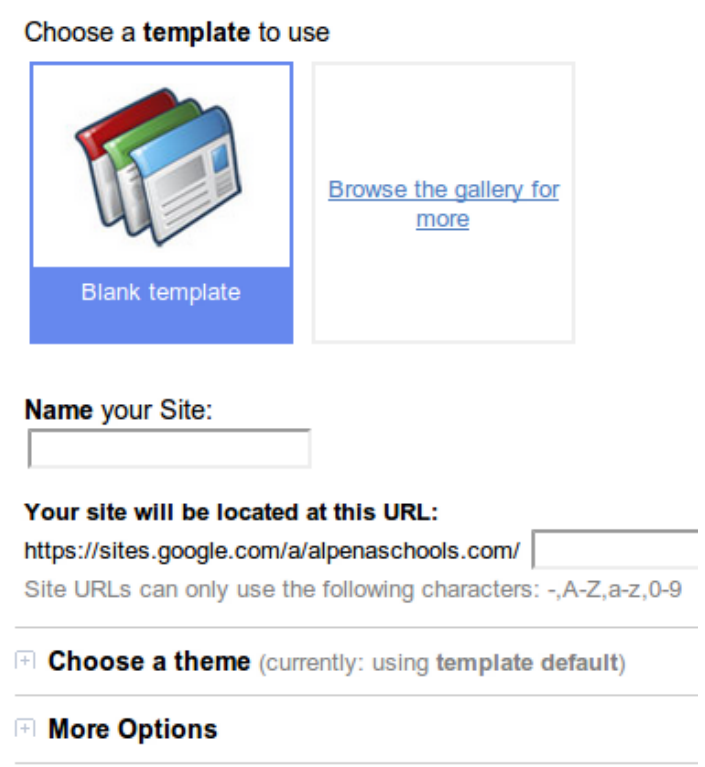

\section{Create site Cancel}

Figure 4. Creating a new website.

Once a site is created, formatting text, adding illustrations, and inserting hyperlinks on a page are all accomplished through an interface that looks very much like a word processing program. Figure 5 shows the editing toolbar in one of the Math Mentors pages.

\section{Google sites Introduction (3) Public on the web

Insert Format Table Layout
$i \sim$ Normal

Figure 5. Editing toolbar in Google Docs. 
We created hyperlinks to several of our documents stored in Google Docs in order to share information on the Math Mentors site. Creating a hyperlink to a document on a page in Google Sites begins with entering the text that will be displayed on the web page. This text will become the link. In another browser window, open the target document in Google Docs. Since the document is stored online, it has a unique web address, or URL. Copy the document's URL from the browser's address bar by selecting it, right-clicking, and choosing "Copy." Back on the web page, highlight the text that was previously entered to convert to the link. Click the "Link" tool in the toolbar. The box shown in Figure 6 will display. Note that it is possible to link to an existing page within the site or to a different web address or URL. Right-click to paste the copied URL in the space provided and click "OK." The link now leads to the stored document.

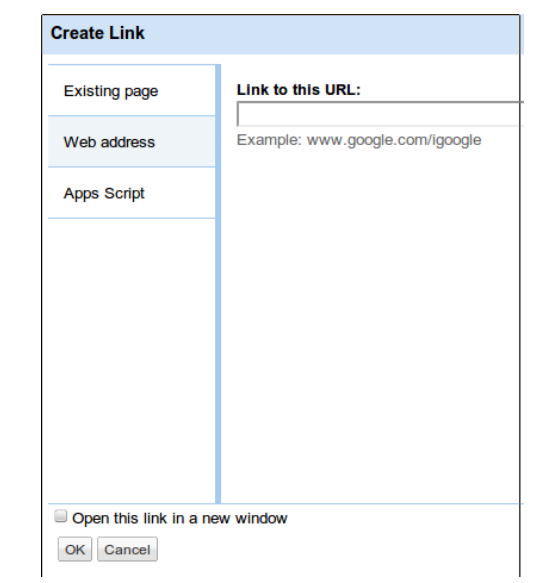

Figure 6. Linking page with an URL.

We followed this procedure to link to our project budget on the site's "Finance" page and to the topic and activity list on our "Resources" page.

\section{Summary Comments}

Our professor for the online course held the same expectations that all of our professors have held: as modern professionals and educational leaders, we are expected to have a firm grasp of standard technological productivity tools. Furthermore, we are expected to demonstrate a willingness to embrace new technology tools as they provide new ways to collaborate, engage stakeholders, and enliven content.

For the members of our class, this was our first experience with Wimba Classroom, which is the university's software of choice because it allows students to interact and build relationships as part of the learning process through the use of audio, video, application sharing, content display, polling, whiteboarding, MP3 and MP4 downloads. We had participated in the traditional synchronous environment of face-toface classes and the asynchronous environment of the Blackboard discussion board. However, the Wimba environment provided us with another sort of learning structure, which combined synchronous interaction with the ability to meet from various locations. As professionals, we had all engaged in webinars for distance learning, but 


\section{Shinsky \& Stevens/TEACHING USING WEB 2.0 APPLICATIONS}

the level of interaction provided by the Wimba Classroom went far beyond what is normally offered in a webinar. We were able to share visual and audio content, the shared desktop, and chat windows. However, the ability to participate in small-group sessions really challenged us to rethink the possibilities of how to engage a wider range of learners and learning styles.

Google Apps definitely was a vehicle that enhanced our learning experience. Our team modeled many of the course goals, demonstrating collaboration and coordination of resources, through the real-life activities we pursued to complete our project. We were not just assembling a presentation, but building an online structure for the implementation of an actual activity, and our final product reflected this. Google Apps is more than just a listing of ideas. It is the foundation and framework for an achievable community engagement program that can have a positive effect on student achievement.

Working with cloud-based tools improved our team members' ability to participate constructively. I worked on a Linux workstation and netbook. Two other team members relied on two different versions of the Windows OS. The fourth team member did his part using the Macintosh OS. Because the Google Apps tools are accessed through an Internet browser, the suite is platform-independent. The fact that we worked with four different operating systems had no influence on our ability to work together.

Another advantage to the Google Apps suite is that we did not have to have common application software installed on our personal workstations. Working with a cloud-based suite, it did not matter that all of our team members did not have access to the same office productivity software or website development programs.

Our work in the online course offered us the opportunity to examine technology as a fully integrated work environment, not just an add-on. The Math Mentors project was one example of this. Other examples included using the Blackboard forums for asynchronous group discussion and experiencing synchronous connection through Wimba sessions. These various modes of collaboration helped model the community school philosophy upon which the course was based. It was a very real demonstration of how school leaders can support the kinds of partnerships that can foster growth for students.

For our team, the influence of our experience with these collaborative technologies went beyond this online course. As we progressed through the university's Educational Specialist program, we found ways to use the Google Docs presentation tools to collaborate on slideshows and drawings for other courses. Outside the classroom, we have found the Google Apps forms tool useful for internal and external surveys for our district, gauging employee reaction to professional development opportunities, and gathering stakeholder input about various school programs. We are sharing information with our internal and external audiences through the Google calendar tools and expanded use of the Google website creation program.

Since our district's adoption of Google Apps for Education in the fall of 2009, the product has seen continued development. This is one of the benefits of cloud-based 
tools; new features are added all the time. Applications such as video chat have been added to the Google Apps suite. Many of the existing Google Apps tools have had feature enhancements to make them work more like the desktop applications they seek to replace. The addition of new capabilities is occurring almost weekly, and there has been no cost to us as end-users. It is no wonder that a growing number of educational institutions have adopted Google Apps and other similar cloud-based services for use by their faculty and students.

The $21^{\text {st }}$ Century knowledge worker exists in an ecosystem permeated by technology. An ever-improving palate of Web 2.0 tools - most of which are free - is available to inspire, empower, and support a quantum leap in collaboration. Our team was encouraged to pursue and explore these capabilities in the context of a rigorous, relevant project. The result has been a stepping stone to real collaboration in the workplace. This project has become an integral part of our district's effort to build partnerships to support parent involvement and student achievement. In addition, I am also very excited about the opportunity to expand my scholarly work in the future, as I will be working with my professor to continue to collect data on online instruction to inform future practices that will enhance the online experience for students in the Educational Leadership program.

\section{Final Thoughts}

The final project shared in this article reflects the combination of strategies and tools utilized to ensure that (a) the students enjoyed using technology and saw the potential for its application in the field, (b) course objectives were achieved, (c) technology awareness and skills were enhanced, and (d) the final project was authentic and would have a positive influence in the education environment. The planning and preparation of the course - along with strategic design to build a learning community, introduce technology with sensitivity to the knowledge and skills of the students, and utilize various tools to facilitate collaboration and access to information and resources - were critical to ensure this was a meaningful learning experience for all the students.

While much of the information shared in this article reflects what has taken place in one online course in the program, ongoing revisions continue to be made to incorporate new technologies, more authentic activities, and exposure to additional research and expert resources in the field. There is no question that Web 2.0, and all of its related and evolving tools, continues to reshape the way we provide online education and enhance our ability as professors to make online education a meaningful learning experience for our students.

\section{References}

Abrego, J. J., \& Pankake, A. (2010). Pk-12 virtual schools: The challenges and roles of school leaders. Educational Considerations, 37(2), 7-13. 
Anderson, R., \& Dexter, S. (2005). School technology leadership: An empirical investigation of prevalence and effect. Educational Administration Quarterly, 41, 49-82.

Barnett, D. R. (2010). Adult education: Motivation and recruitment of working adults in the pursuit of higher education. Thesis Paper: Southern Illinois University Carbondale. Retrieved from http://opensiuc.lib.siu.edu/cgi/ viewcontent.cgi?article $=1356 \&$ context=theses

Byun, H. P., Hallett, K., \& Essex, C. (2000). Supporting instructors in the creation of online distance education courses: Lessons learned. Educational Technology, 40(5), 57-60.

Carroll, J. (2011). From encyclopedias to search engines: Technological change and its impact on literacy learning. Literacy Learning: The Middle Years, 19(2). Retrieved from http:// www.freepatentsonline.com/article/Literacy-Learning-MiddleYears/259959924.html

Christensen, R. (2002). Effects of technology integration education on the attitudes of teachers and students. Journal of Research on Technology in Education, 34(4), 411433.

Churches, A. (2009). Bloom's Digital Taxonomy. Retrieved from http://edorigami.wikispaces.com/Bloom\%27s+Digital+Taxonomy\#Bloom's Digital Taxonomy

Conole, G., \& Alevizou, P. (2010). A literature review of the use of web 2.0 tools in higher education. Higher Education Academy. Retrieved from http://www.heacademy.ac.uk/assets/EvidenceNet/Conole_Alevizou_2010.pdf

Culp, K. M., Honey, M., \& Mandinach, E. (2005). A retrospective on twenty years of education technology policy. Journal of Educational Computing Research, 32(3), 279307.

Educational Leadership Constituent Council (ELCC). (2002). Standards for Advanced Programs in Educational Leadership. Retrieved from http://www.npbea.org/ELCC/ELCCStandards\%20_5-02.pdf

Edutopia Staff. (2008, March 17). Why integrate technology into the curriculum? The reasons are many. Edutopia. Retrieved from http://www.edutopia.org/technology-integration-introduction 
Ginsburg, L., Sabatini, J., \& Wagner, D. A. (2010). Basic skills in adult education and the digital divide. Learning to Bridge the Digital Divide, 77-89. Retrieved from http://www.oecd.org/dataoecd/24/12/41284692.pdf

Grey-Bowen, J. E. (2010). A study of technology leadership among elementary public school principals in miami-dade county. Dissertation submittal to the graduate faculty of St. Thomas University. Retrieved from http://rer.sagepub.com.ezproxy.mnl.umkc.edu/content/78/3/676

Groth, L. A., Dunlap, K. L., \& Kidd, J. K. (2007). Becoming technologically literate through technology integration in pk-12 preservice literacy courses: Three case studies. Reading Research and Instruction, 46(4), 363-386.

Herder, E., \& Marenzi, I., (Eds.). (2010). D1.2 trends in connecting learners: First research \& technology scouting report. Retrieved from http://dspace.ou.nl/bitstream/1820/2824/1/stellar_d1-2 trends-inconnecting-learners.pdf

Hill, J. R. (2002). Strategies and techniques for community building in web-based learning environments. Journal of Computing in Higher Education, 14(1), 67-86.

Jackson, D. B. (2009). Relationship between principals' technological leadership and their schools' implementation of instructional technology (Doctoral dissertation). Retrieved from

http://www.georgiasouthern.edu/etd/archive/spring2009/dandrea_b_jackson Ljackson_dandrea_b_200901_edd.pdf

Kent, T. W., \& McNergney, R. F. (1999). Will technology really change education? From blackboard to web. Thousand Oaks, CA: Corwin Press, Inc.

Kidd, T. (2010). Online education and adult learning: New frontiers for teaching practices. Information Science Reference. Hershey, PA: IGI Global.

Kingsley, K. V. (2010). Technology-mediated critical literacy in k-12 contexts: Implications for $21^{\text {st }}$ century teacher education. Journal of Literacy and Technology, 11(3), 2-39.

Liu, M. C. (2001). A systematic web-course development process: User-centered requirements. Educational Technology, 41(6), 15-22.

Liu, X., Magjuka, R. J., Bonk, C. J., \& Lee, S. (2007). Does sense of community matter? An examination of participants' perceptions of building learning communities in online courses. The Quarterly Review of Distance Education, 8(1), 9-24. Retrieved 
from

http://books.google.com/books?hl=en\&lr=\&id=TX6FOLBLTNcC\&oi=fnd\&pg= PA9\&dq $=\% \mathrm{E} 2 \% 80 \%$ A2 $\% 09$ Online + courses + can + promote + isolation + unless + the +instructor+encourages+participation+to+promote+a+sense+of+belonging + and +value\&ots $=F k C 2 x G 8 R m a \& s i g=Y Z y X j h E 3 d F E V e N d 3017 M R b q U i Q g \# v=$ onepage $\underline{\& q} \& \mathrm{f}=$ false

Michigan Department of Education. (2009). Program Standards for the Preparation of Central Office Administrators. Lansing, MI: State of Michigan.

Northcote, M. (2008). Sense of place in online learning environments. Proceedings Ascilite Melbourne 2008. Retrieved from http://www.ascilite.org.au/conferences/melbourne08/procs/northcote.pdf

Norton, P., \& Hathaway, D. (2008). Exploring two teacher education online learning designs: A classroom of one or many? Journal of Research on Technology in Education, 40(4), 475-496.

Palloff, R. M., \& Pratt, K. (2011). The excellent online instructor: Strategies for professional development. San Francisco: Jossey-Bass. Retrieved from http:/ / books.google.com/books?hl=en\&lr=\&id=GY9pmmBAhy0C\&oi=fnd\&pg $=$ PT7\&dq $=\% \mathrm{E} 2 \% 80 \% \mathrm{~A} 2 \% 09$ Online + courses + can + promote + isolation + unless + the +instructor+encourages + participation+to+promote+a+sense+of+belonging +and +value\&ots=ZFQyrork22\&sig=KM57adRBezSWxTue3boWBb_hH20\#v=onepage $\underline{\text { \& \& } \mathrm{f}=\text { false }}$

Partnership for 21st Century Skills. (2002). Learning for the 21st century: A report and mile guide for 21st century skills. Retrieved from http://www.21stcenturyskills.org/images/stories/otherdocs/p21up_Report.pd $\underline{f}$

Pasco, B., \& Adcock, P. (2007). New rules, new roles: Technology standards and teacher education. Educational Considerations, 34(2), 29-31.

Reushle, S. (2006). A framework for designing higher education e-learning environments. Retrieved from http://eprints.usq.edu.au/1226/1/reushle06.pdf

Reynolds, R., \& Caperton, I. H. (2009). The emergence of six contemporary learning abilities (6-CLAs) in middle school, high school and community college students as they design web-games and use project-based social media in globaloria. Paper presented at the meeting of AERA 2009, San Diego, CA. Retrieved from http://worldwideworkshop.org/pdfs/Globaloria-EmergencofSixCLAs.pdf 
Rice, K. (2009). Priorities in k-12 distance education: A delphi study examining multiple perspectives on policy, practice, and research. Educational Technology E Society, 12 (3), 163-177.

Sander, L. (2010). Colleges woo adults who have some credits but no degree. The Chronicle of Higher Education. Retrieved from http:/ / cpe.ky.gov/NR/rdonlyres/3598C4AF-2056-4B0A-A8CDF539FA223D62/0/8_AdultLearnerInitiative.pdf

Spangle, M., Hodne, G., \& Schierling, D. (2002). Approaching value-centered education through the eyes of an electronic generation: Strategies for distance learning. Paper presented at the meeting of the National Communication Association, New Orleans, LA. Retrieved from ERIC database. (ED474581)

Thomas, L. G., \& Knezek, D. G. (2008). Information, communications, and educational technology standards for students, teachers, and school leaders. Springer International Handbooks for Education, 20(4), 333-348.

Tricker, T., Rangecroft, M., Long, P., \& Gilroy, P. (2001). Evaluating distance education courses: The student perception. Assessment $\mathcal{E}$ Evaluation in Higher Education, 26(2), 165-177.

Woo, Y., Herrington, J., Agostinho, S., \& Reeves, T. C. (2007). Implementing authentic tasks in web-based learning environments: The instructor's inclusion of authentic activities improves the quality of student interaction and learning in online classrooms. Educause Quarterly Magazine, 30(3), 36-43. Retrieved from http://www.utsweb.net/instructional\%20design\%20resources/implementing_a uthentic_tasks_in_web.pdf

Young, S. (2006). Student views of effective online teaching in higher education. The American Journal of Distance Education, 20(2), 65-77.

Zemsky, R., \& Massy, W. (2004). Thwarted innovation: What happened to elearning and why? A final report for the Weatherstation Project of the Learning Alliance at the University of Pennsylvania. Retrieved from http:/ / www.thelearningalliance.info/Docs/Jun2004/ThwartedInnovation.pdf 